\title{
Estrogen Upregulates T-Type Calcium Channels in the Hypothalamus and Pituitary
}

\author{
Jian Qiu, ${ }^{1 \star}$ Martha A. Bosch, ${ }^{1,2 *}$ Khalid Jamali, ${ }^{1}$ Changhui Xue, ${ }^{1}$ Martin J. Kelly, ${ }^{1}$ and Oline K. Rønnekleiv ${ }^{1,2}$ \\ ${ }^{1}$ Department of Physiology and Pharmacology and ${ }^{2}$ Division of Neuroscience, Oregon National Primate Research Center, Oregon Health and Science \\ University, Portland, Oregon 97239-3098
}

Low voltage-activated (T-type) $\mathrm{Ca}^{2+}$ channels are responsible for generating low-threshold spikes (LTS) that facilitate burst firing and transmitter release in neurons. The T-type $\mathrm{Ca}^{2+}$ channels contain a regulatory $\alpha 1$ subunit, and several isoforms of the $\alpha 1$ subunit (Cav3.1, 3.2, 3.3) have been cloned. The Cav $3.1 \alpha 1$ subunit is abundantly expressed in the hypothalamus. Previously, we found that 17 $\beta$-estradiol (E2) increased the number of arcuate neurons expressing LTS. Therefore, we used an ovariectomized female guinea pig model to measure the distribution and regulation of Cav3.1 mRNA expression by E2. Guinea pig Cav3.1 $\alpha 1$ subunit sequences, which were cloned by PCR, were used in ribonuclease protection (RPA) and in situ hybridization assays to evaluate mRNA expression. Based on a RPA, E2 significantly increased the mRNA expression of Cav3.1 $\alpha 1$ subunit in the mediobasal hypothalamus and the pituitary. In situ hybridization analysis revealed that $\mathrm{E} 2$ significantly increased Cav $3.1 \mathrm{mRNA}$ expression in medial preoptic nuclei, bed nuclei stria terminalis, and the arcuate nucleus. Whole-cell patch recordings in arcuate neurons revealed that E2 treatment significantly increased the peak T-type $\mathrm{Ca}^{2+}$ current density by twofold without affecting the activation/inactivation characteristics and augmented the rebound excitation by threefold to fourfold. These results suggest that estrogen regulates the mRNA expression of T-type calcium channels, which leads to increased functional expression of the channel. Increased expression of T-type channels could be one mechanism by which estrogen augments burst firing and transmitter release in hypothalamic neurons.

Key words: estrogen regulation; Cav3.1 mRNA; T-current amplitude; rebound burst firing; dopamine; POMC; neurons

\section{Introduction}

Voltage-gated $\mathrm{Ca}^{2+}$ channels are critical for controlling calcium entry in hypothalamic neurons and in pituitary cells (Van Goor et al., 2001; Perez-Reyes, 2003; Stojikovic et al., 2005). These channels represent a heterogenous family of calcium-selective channels that are commonly known for their strong sensitivity to voltage. They can, however, be distinguished by their molecular, electrophysiological, and pharmacological characteristics. Among this family, the low voltage-activated T-type for "transient" current, as opposed to L-type, for "long-lasting" current, are thought to be involved in pacemaker activity, neuronal oscillations and resonance, and rebound burst firing (Perez-Reyes, 2003). Hypothalamic neurons, similar to thalamic neurons, use low threshold spikes (LTSs) to support burst firing activity (McCormick and Huguenard, 1992; Erickson et al., 1993b; Williams et al., 1997; Sundgren-Andersson and Johansson, 1998; Wagner et al., 2000; Kim et al., 2001; Chemin et al., 2002; Perez-Reyes, 2003; van den Top et al., 2004). Low-threshold calcium spikes evoke several fast $\mathrm{Na}^{+}$action potentials and therefore are involved in signal amplification in CNS neurons. The occurrence of

\footnotetext{
Received March 23, 2006; revised Sept. 15, 2006; accepted Sept. 19, 2006.

This work was supported by United States Public Health Grants NS43330, NS38809, and DK68098. We recognize the skilled technical assistance of Rebecka Amodei.

*.Q. and M.A.B. contributed equally to this work.

Correspondence should be addressed to Dr. Oline K. Rønnekleiv, Department of Physiology and Pharmacology,

L334, Oregon Health and Science University, Portland, OR 97239-3098. E-mail: ronnekle@ohsu.edu.

DOI:10.1523/JNEUROSCI.3229-06.2006

Copyright $\odot 2006$ Society for Neuroscience ～0270-6474/06/2611072-11\$15.00/0
}

LTS is prevalent in rat and guinea pig hypothalamic neurons (Erickson et al., 1993b; Hoffman et al., 1994; Fisher and Bourque, 1995; Niespodziany et al., 1999; Wagner et al., 2000), and we found that the number of arcuate neurons expressing lowthreshold spikes is increased with estrogen treatment (Kelly and Rønnekleiv, 1994). Voltage-clamp studies have revealed that a relative fast and large inward current, which exhibits activation/ inactivation characteristics analogous to the T-type calcium channels, underlies the LTS. T-type channels are shown to contribute to a transient inward current, and several isoforms of the T-channel subunits have been cloned (Cav 3.1, 3.2, 3.3) (PerezReyes et al., 1998; Lee et al., 1999). The calcium channels are complex proteins composed of four to five distinct subunits: $\alpha 1$, $\alpha 2, \beta, \delta$, and $\gamma$ (Catterall et al., 2003). The $\alpha 1$ subunit is the largest and contains the conduction pore, as well as known binding sites for regulation by drugs and second messengers (Catterall et al., 2003, 2005). The biophysical properties of T-type channels differ among the different isotypes, and the current profiles of Cav 3.1 and 3.2, versus Cav 3.3, are fairly similar, and these channels are involved in short burst firing in thalamocortical relay neurons (Chemin et al., 2002). The mRNA and protein of the $\alpha 1$ subunit of the Cav 3.1 channel are highly expressed in the hypothalamus (Craig et al., 1999; Talley et al., 1999). The $\alpha 1$ subunit of Cav 3.2 and Cav 3.3 channels are also present but at much lower levels (Craig et al., 1999; Talley et al., 1999). Very little is known about the physiological regulation of these channels in the hypothalamus and especially the gonadal steroid regulation of their expression. Therefore, in our current studies, we aimed to document 
the mRNA expression profile of the $\alpha 1$ subunit of the T-type calcium channel Cav3.1 in the guinea pig diencephalon and explore its modulation by $17-\beta$ estradiol (E2). Our findings suggest that the mRNA expression of the Cav3.1 $\alpha 1$ subunit is increased by $\mathrm{E} 2$ in a number of hypothalamic nuclei and the pituitary. In addition, we recorded an increase in the whole-cell T-type current density as well as an increase in rebound burst firing in arcuate neurons from E2-treated animals, which is an indication that the increased mRNA expression leads to increased excitability of arcuate neurons.

\section{Materials and Methods}

Animals. Adult female (Topeka) guinea pigs were maintained under constant temperature and light (lights on between 6:30 A.M. and 8:30 P.M. local time) with food and water provided ad libitum. Animal care and use were approved by an institutional committee and were according to National Institutes of Health and International guidelines. The animals were ovariectomized under ketamine/xylazine anesthesia $(33 / 6 \mathrm{mg} / \mathrm{kg}$, s.c.) 5-6 d before experimentation and given a subcutaneous injection of either $17 \beta$-estradiol (E2) in the form of $17 \beta$-estradiol benzoate (here referred to as E2; $25 \mu \mathrm{g}$ in $0.1 \mathrm{ml}$ ) or sesame oil vehicle $(0.1 \mathrm{ml})$. Twentyfour hours later, the animals were killed by decapitation after sedation with ketamine, and blood samples were collected. Serum estrogen concentrations were determined by radioimmunoassay as described previously (Jamali et al., 2003). Brains were removed quickly and rinsed in chilled phosphate buffered solution.

Tissue preparation. For ribonuclease protection assay (RPA) analysis, a brain slicer (EM Corporation, Chestnut Hill, MA) was used to produce 2-3 mm frontal blocks, and the preoptic area (POA) and mediobasal hypothalamus (MBH) were dissected. The POA block included the ventral parts of the bed nucleus of the stria terminalis, medial and lateral POAs, anterior hypothalamic nucleus, and periventricular nucleus. The $\mathrm{MBH}$ is referred to as the hypothalamic area extending from the end of the retrochiasmatic area to the beginning of the mammillary bodies and dorsally to the midlevel of the third ventricle. The pituitary was also harvested. Tissues were rapidly frozen in isopentane and then stored at $-80^{\circ} \mathrm{C}$. Total RNA was extracted using TRIzol reagents (Invitrogen, Gaithersburg, MD) according to directions of the manufacturer, and the concentration was determined by spectrophotometry. For in situ hybridization, 2-3 mm coronal blocks through the POA and $\mathrm{BH}$ were fixed in $4 \%$ paraformaldehyde for $6 \mathrm{~h}$, soaked in 20\% buffered-sucrose solution, pH 7.4, embedded in OCT (Sakura Finetek, Torrance, CA), and frozen in isopentane at $-55^{\circ} \mathrm{C}$. Coronal sections $(15 \mu \mathrm{m})$ were cut on a cryostat and thaw-mounted onto Superfrost Plus glass slides (Fisher Scientific, Pittsburgh, PA). The sections were stored at $-80^{\circ} \mathrm{C}$.

Cloning of the guinea pig T-type calcium channel (Cav3.1/ $\alpha 1 G$ ). A 378 bp fragment of the guinea pig Cav3.1 $\alpha 1$ subunit gene was cloned (GenBank accession number DQ 992353) using reverse transcription (RT) and PCR. Oligonucleotide primers were designed based on homology between human, rat, and mouse sequences using the Clone Manager 5 software. The $5^{\prime}$ primer (5'-AGGAGTCCACCTGCTACAA-3') was $100 \%$ homologous to the human (AF126966; 5523-5541 bp), rat (AF027984; 5836-5854 bp), and mouse (AJ012569; 5582-5600 bp) T-type calcium channel Cav3.1 sequences. The $3^{\prime}$ primer (5'CAGACTTCCGCACAGTCA-3') was $100 \%$ homologous to the human (5895-5912 bp) sequence and $94.4 \%$ homologous to both the rat (6217$6234 \mathrm{bp}$ ) and mouse (5966-5983 bp) sequences. Primer synthesis by Invitrogen included at the $5^{\prime}$-end of both primers a 12 base extension of deoxy-UMP residues used with the PCR cloning kit CloneAmp pAMP10 System (Invitrogen).

The Cav3.1 cDNA was amplified from 200 ng of total RNA extracted from the guinea pig hypothalamus using RT-PCR (GeneAmp kit; PerkinElmer, Foster City, CA). An Oligo-DT primer was used for the cDNA first-strand synthesis. Reverse transcription was performed for 15 min at $42^{\circ} \mathrm{C}$. PCR was conducted for 45 cycles of denaturation $\left(94^{\circ} \mathrm{C}\right.$; $45 \mathrm{~s})$, annealing $\left(56^{\circ} \mathrm{C} ; 45 \mathrm{~s}\right)$, and extension $\left(72^{\circ} \mathrm{C} ; 1 \mathrm{~min} 10 \mathrm{~s}\right)$, with a 7 min final extension. The resulting $378 \mathrm{bp}$ product was gel-purified, sub- cloned into the pAMP10 vector by using the CloneAmp System, and sequenced.

Ribonuclease protection assay. The antisense Cav3.1 riboprobe was labeled by in vitro transcription with $\left[{ }^{32} \mathrm{P}\right] \mathrm{rUTP}$ (PerkinElmer) and was purified using the Fullengther Preperative Gel Apparatus (BioKey American Instrument, Aloha, OR). The RPA was performed using the RPA II kit (Ambion, Austin, TX) as described previously (Jamali et al., 2003). Briefly, the Cav3.1 probe was incubated with 5-10 $\mu$ g of total RNA or $125-4000$ fg of sense standard RNA overnight at $42^{\circ} \mathrm{C}$. Hybridization was terminated by ribonuclease digestion; the protected fragments were loaded onto an acrylamide gel and exposed to film for visualization. Quantification was performed using a PhosphorImager (Bio-Rad, Hercules, CA). The amount of Cav3.1 mRNA in each sample was quantified according to the sense standard curve. The values obtained were then normalized to the corresponding cyclophilin levels (Ma et al., 1996). RNA from oil- and E2-treated animals were always assayed together, and comparison between the two groups was performed using a two-tailed paired Student's $t$ test. Differences were considered statistically significant if the probability of error was $<5 \%$.

In situ hybridization. Radioactive antisense cRNA probe was transcribed in vitro with T-7 RNA polymerase from the HindIII-linearized guinea pig Cav3.1 construct, and the sense probe was prepared by using SP6 polymerase in the presence of ${ }^{35}$ S-uridine $5^{\prime}(\alpha$-thio)triphosphate. Residual DNA was digested with 10 U DNase I (Roche, Indianapolis, IN). The antisense and sense RNA probes were separated on G-50 Sephadex column (GE Healthcare, Piscataway, NJ). Slides from oil- and estrogentreated females were always reacted together. These slides were postfixed in fresh $4 \%$ paraformaldehyde in Sorensen's phosphate buffer $(0.03 \mathrm{M}$, $\mathrm{pH}$ 7.4) for $15 \mathrm{~min}$, rinsed in Sorensen's buffer, and treated with proteinase $\mathrm{K}(1.0 \mu \mathrm{g} / \mathrm{ml})$ for 3-6 min at room temperature. Sections were then treated with $0.1 \mathrm{M}$ triethanolamine $(3-5 \mathrm{~min})$, followed by $0.25 \%$ acetic anhydride in $0.1 \mathrm{M}$ triethanolamine $(10 \mathrm{~min})$, and rinsed briefly in $2 \times$ SSC. Sections were prehybridized for $1 \mathrm{~h}$ at $58^{\circ} \mathrm{C}$ with hybridization buffer $(50 \%$ formamide, $1 \times$ Denhardt's solution, $10 \%$ dextran sulfate, $100 \mu \mathrm{M}$ dithiothreitol, $200 \mathrm{~mm}$ sodium chloride, $10 \mathrm{~mm}$ Tris- $\mathrm{HCl}, \mathrm{pH}$ 8.0, $1 \mathrm{~mm}$ EDTA, pH 8.0, $125 \mu \mathrm{g} / \mathrm{ml}$ tRNA; Sigma, St. Louis, MO), and then quickly rinsed in $2 \times$ SSC buffer. The ${ }^{35} S$-labeled antisense and sense riboprobes were heat-denatured, diluted with hybridization buffer, and used at a final concentration of $1.2 \times 10^{4} \mathrm{cpm} / \mu \mathrm{l}$. Subsequently, the sections were covered with glass coverslips, sealed, and hybridized in a moist chamber for at least $20 \mathrm{~h}$ at $59^{\circ} \mathrm{C}$. After hybridization, the slides were rinsed in $2 \times$ SSC buffer, reacted with RNase $(20 \mu \mathrm{g} / \mathrm{ml})$ for $45-60$ $\mathrm{min}$ at room temperature, and washed in decreasing concentrations of SSC $(2 \times, 1 \times, 0.5 \times, 0.1 \times)$ at $55^{\circ} \mathrm{C}$ with a final wash for $1 \mathrm{~h}$ in $0.1 \times$ SSC at $65^{\circ} \mathrm{C}$. The slides from oil- and estrogen-treated females were dehydrated in ethanol, placed side by side on a flat surface and together with autoradiographic ${ }^{14} \mathrm{C}$ microscales were exposed to Hyperfilm- $\beta \max$ (GE Healthcare) for $5 \mathrm{~d}$ at $4^{\circ} \mathrm{C}$. The slides were then dipped in Kodak (Rochester, NY) NTB2-type nuclear track emulsion and exposed for $14 \mathrm{~d}$ at $4^{\circ} \mathrm{C}$. Thereafter, slides were developed in D19 developer, fixed in Kodak fixer, counterstained with Hematoxylin, dehydrated, and coverslipped. Quantification of film images was performed using a Macintosh G4 computer equipped with NIH Image 1.61 program. Film images of four to nine sections from the POA, bed nucleus stria terminalis (BSTN), basal hypothalamus (BH), and the medial thalamus from matched oil control and E2-treated females were analyzed, and an average density value was obtained from each brain region, which was used for additional analysis. The ${ }^{14} \mathrm{C}$ microscale was used as a standard to calculate the density of Cav3.1 mRNA signals, and the optical density was converted to nanocuries per gram. Comparisons between the two groups were performed using a two-tailed Student's $t$ test. Differences were considered statistically significant if the probability of error was $<5 \%$.

Emulsion-coated slides of Cav3.1 images were analyzed and photographed using a Nikon E800 microscope (Melville, NY). Dark-field views of photomicrographs were illustrated from film negatives using a film scanner (Sprint Scan 35 Plus; Polaroid, Cambridge, MA), and the Adobe Photoshop (Adobe Systems, Mountain View, CA) and Macromedia FreeHand (San Francisco, CA) software programs. Contrast and brightness were adjusted in scanned images to match the original photographs. 
Estrogen response elements. The human and mouse Cav3.1 genes were analyzed to look for estrogen response elements (EREs) using the Dragon Estrogen Response Element Finder, version 2 (Bajic et al., 2003). This program is designed for the specific discovery of EREs in DNA sequences. The consensus ERE is 5'GGTCAnnnTGACC-3', where $\mathrm{n}$ can be any nucleotide. To model the ERE, the program uses the Position Weight Matrix method in addition to the probability of pairing the halfsites by the transitional probabilities of the $3^{\prime}$ nucleotide of the $5^{\prime}$ half-site to the $5^{\prime}$ nucleotide of the $3^{\prime}$ half-site, ignoring spacer nucleotides. Details can be found on-line (http://sdmc.lit.org.sg/ERE-V2/index).

Electrophysiology. The T-type $\mathrm{Ca}^{2+}$ current was characterized in arcuate nucleus neurons from adult oil- and E2-treated, ovariectomized female guinea pigs using whole-cell patch recording. Coronal slices $(300 \mu \mathrm{m})$ through the rostrocaudal extent of the arcuate nucleus were prepared as described previously (Qiu et al., 2003). For whole-cell recordings, electrodes were fabricated from borosilicate glass $(1.5 \mathrm{~mm}$ outer diameter; World Precision Instruments, Sarasota, FL). Electrodes were filled with an internal solution with $0.25 \%$ biocytin and containing the following (in $\mathrm{mM}$ ): $128 \mathrm{~K}^{+}$gluconate, $10 \mathrm{NaCl}, 1 \mathrm{MgCl}_{2}, 11$ EGTA, 10 HEPES, 1.2 ATP, and 0.4 GTP (pH was adjusted to 7.37.4 with $1 \mathrm{~N} \mathrm{KOH}, 272-315$ mOsm). Calcium currents were recorded using the artificial CSF (aCSF) (in mm: $124 \mathrm{NaCl}, 26 \mathrm{NaHCO}_{3}, 10 \mathrm{dex}-$ trose, 10 HEPES, $5 \mathrm{KCl}, 2.6 \mathrm{NaH}_{2} \mathrm{PO}_{4}, 2$ $\mathrm{MgSO}_{4}$, and $2 \mathrm{CaCl}_{2}$ ) plus tetrodotoxin (TTX) (1 $\mu \mathrm{M}$; Alomone Labs, Jerusalem, Israel), tetraethylamonium (TEA; $5 \mathrm{~mm}$ ), and 4-aminopyridine ( $3 \mathrm{~mm}$ ) to block the fast $\mathrm{Na}^{+}$ and residual $\mathrm{K}^{+}$channels. Standard whole-cell recordings were made using an Axo-patch $1 \mathrm{D}$ as described previously (Qiu et al., 2003). Membrane currents underwent analog-to-digital conversion via a Digidata 1200 interface coupled to pClamp 7.0 (Molecular Devices, Union City, CA). Low-pass filtering of the currents was conducted at a frequency of $2 \mathrm{kHz}$. The liquid junction potential was corrected for in subsequent data analysis.

The effects of estrogen treatment on the peak current, peak current density, and activation/inactivation characteristics of T-current were measured. There was no difference in the input resistance (oil, $1.00 \pm$ $0.08 \mathrm{G} \Omega, n=88$; E2, $0.98 \pm 0.07 \mathrm{G} \Omega, n=53$ ) or whole-cell capacitance (oil, $37.75 \pm 2.07 \mathrm{pF}, n=88$; E2, $37.37 \pm 2.97 \mathrm{pF}, n=55$ ) for the two groups of females. For studying the effect of estrogen on the activation/ inactivation characteristics of the $\mathrm{T}$ current, the electrodes were filled with an internal solution with $0.25 \%$ biocytin and consisting of the following (in mM): $100 \mathrm{Cs}^{+}$gluconate, $20 \mathrm{TEACl}, 10 \mathrm{NaCl}, 1 \mathrm{MgCl}_{2}, 10$ HEPES, 11 EGTA, 1 ATP, 0.25 GTP, the $\mathrm{pH}$ was adjusted to 7.3 with $\mathrm{CsOH}$ at $300 \mathrm{mOsm}$. Activation curves were fitted by the Boltzmann equation: $\left.I / I_{\max }=1 /\left\{1+\exp \left[V_{1 / 2}-V s\right) / k\right]\right\}$, where $I$ is the peak current at the step potential $V s, I_{\max }$ is the peak current amplitude, $V_{1 / 2}$ is the step potential yielding half-maximum current, and $k$ is the slope factor. Inactivation curves were fit with the Boltzmann equation: $I / I_{\max }=1-1 /$ $\left\{1+\exp \left[\left(V_{\mathrm{H}}-V_{1 / 2}\right) / k\right]\right\}$, where $I$ is the peak current at the step potential $V_{\mathrm{H}}, I_{\max }$ is the peak current amplitude, $V_{1 / 2}$ is the step potential at which half the current is inactivated, and $k$ is the slope factor. To pharmacologically verify that the calcium current was the T-type, we perfused nickel $\left(\mathrm{Ni}^{2+}, 100 \mu \mathrm{M}\right.$; Upjohn Pharmaceuticals, Kalamazoo, MI) or mibefradil (10 $\mu \mathrm{M}$; Upjohn Pharmaceuticals) (SundgrenAndersson and Johansson, 1998; Catterall et al., 2005) to block the current at the end of the recording $(n=17)$. For measuring the role of the

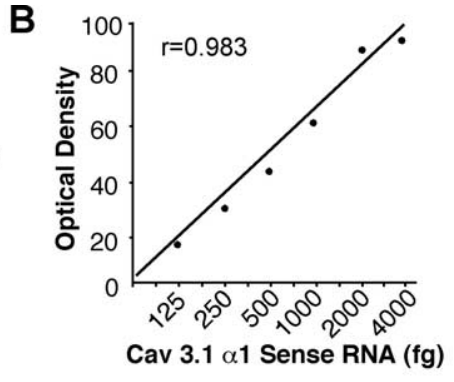

Cav $3.1 \alpha 1$

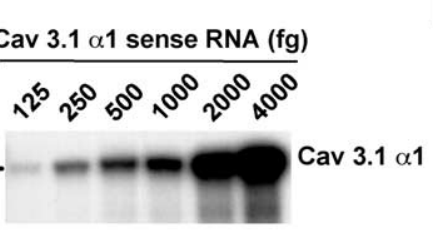

Pit

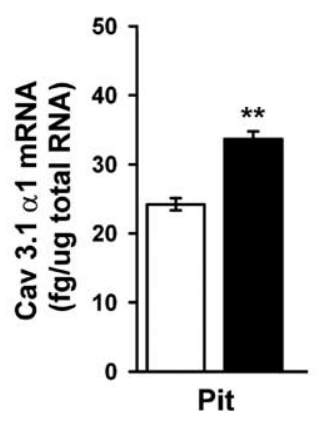

$\mathrm{MBH}$

Pit
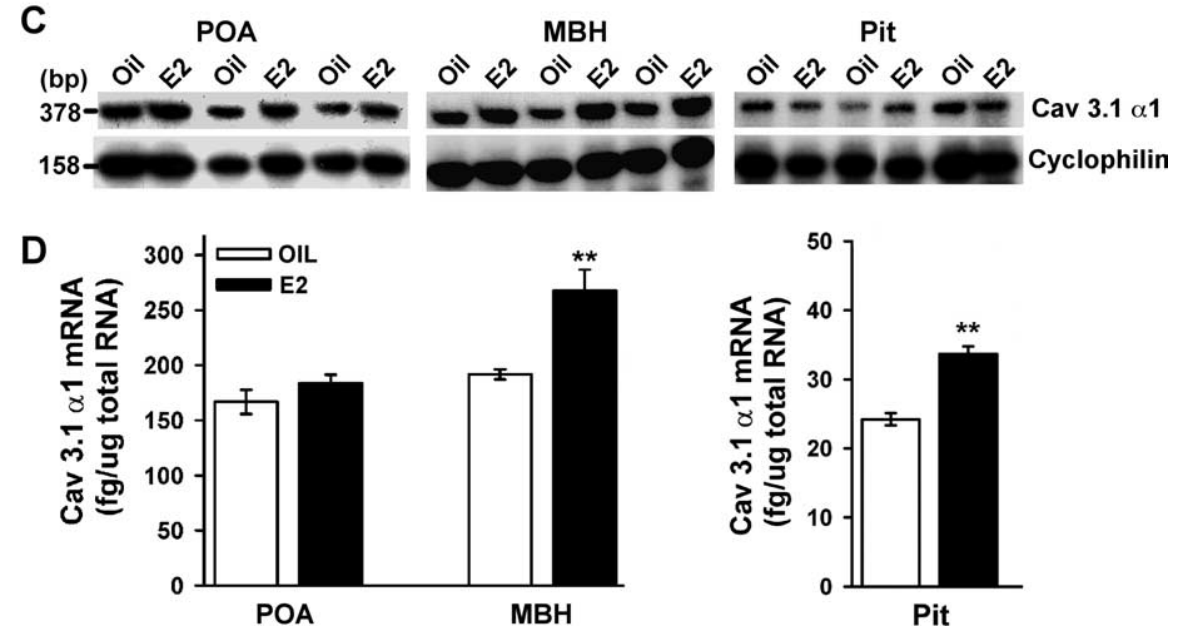

Figure 1. RPA analysis of estrogen effects. $\boldsymbol{A}-\boldsymbol{C}$, Representative RPA assay of total RNA (5 $\mu \mathrm{g} / \mathrm{lane})$ from vehicle- and E2treated $(25 \mu \mathrm{g} ; 24 \mathrm{~h}$ ) animals illustrating the levels of Cav $3.1 \alpha 1 \mathrm{mRNA}$ detected in the POA, MBH, and pituitary (Pit) from individual animals. $\boldsymbol{A}$, Sense RNA (125- $4000 \mathrm{fg}$ ) was used to construct a standard curve. $\boldsymbol{B}$, Linear regression analysis of the Cav3.1 ense standard curve using a Phosphorlmager revealed $r=0.983 . D$. Distribution and quantitative analysis of Cav3.1 $\alpha 1$ The asterisks denote a significant change (paired $t$ test; ${ }^{* *} p<0.01$ ) in the level of (av3.1 $\alpha 1$ mRNA caused by E2 relative to that observed in oil-treated controls. UP, Undigested probe; DP, digested probe.

T-type calcium current on modulating cell firing characteristics and hence the effects of estrogen, we used a standard current-clamp protocol in which the cells were hyperpolarized to $-120 \mathrm{mV}$ (a level at which all of the T-type calcium channels are deinactivated) and then stepped back to the $V_{1 / 2}$ for activation $(-60 \mathrm{mV})$ of T-type current and measured the number of fast $\mathrm{Na}^{+}$spikes riding on the crest of the low threshold spike (over a 500 ms period) (van den Top et al., 2004; Molineux et al., 2006; Zhang et al., 2006). The $\mathrm{Na}^{+}$spikes were blocked by TTX to reveal the underlying LTS, and the LTS was abolished by $\mathrm{Ni}^{2+}$.

Immunocytochemistry. After electrical recording, the slices were prepared for fluorescence immunocytochemistry as described previously (Rønnekleiv et al., 1990; Qiu et al., 2003). Briefly, the slices were fixed in $4 \%$ paraformaldehyde, cryoprotected in sucrose solution, sectioned on a cryostat, and reacted with streptavidin-Cy2 (1:10,000). Sections with biocytin-filled neurons were processed for tyrosine hydroxylase (TH) or $\beta$-endorphin immunoreactivity using a monoclonal antibody to $\mathrm{TH}$ (Diasorin, Stillwater, MN) or a polyclonal antibody to $\beta$-endorphin (Dave et al., 1985) (kindly provided by Dr. Robert Eskay, National Institutes of Health, Bethesda, MD). Sections were incubated overnight with the primary antisera each diluted 1:5000 in dilution buffer containing Tris-(hydroxymethyl)aminomethane (0.5\%; Sigma Chemical) in $0.1 \mathrm{M}$ PBS, $0.7 \%$ seaweed gelatin, $0.4 \%$ Triton $\mathrm{X}-100$, and $3 \% \mathrm{BSA}, \mathrm{pH}$ 7.6. The following day, the sections were washed in PBS and then incubated for $2 \mathrm{~h}$ at room temperature with the Cy3-conjugated secondary antibody, donkey anti-rabbit gamma globulin (IgG; 1:500 in dilution buffer), or antimouse IgG (1:500) for $\beta$-endorphin and TH, respectively. Sections were washed for $4-6 \mathrm{~h}$ in PBS. Coverslips were applied using a glycerol-glycine buffer $(2: 1 ; \mathrm{pH} 8.6)$ containing $5 \% \mathrm{~N}$-propyl gallate to reduce photobleach- 

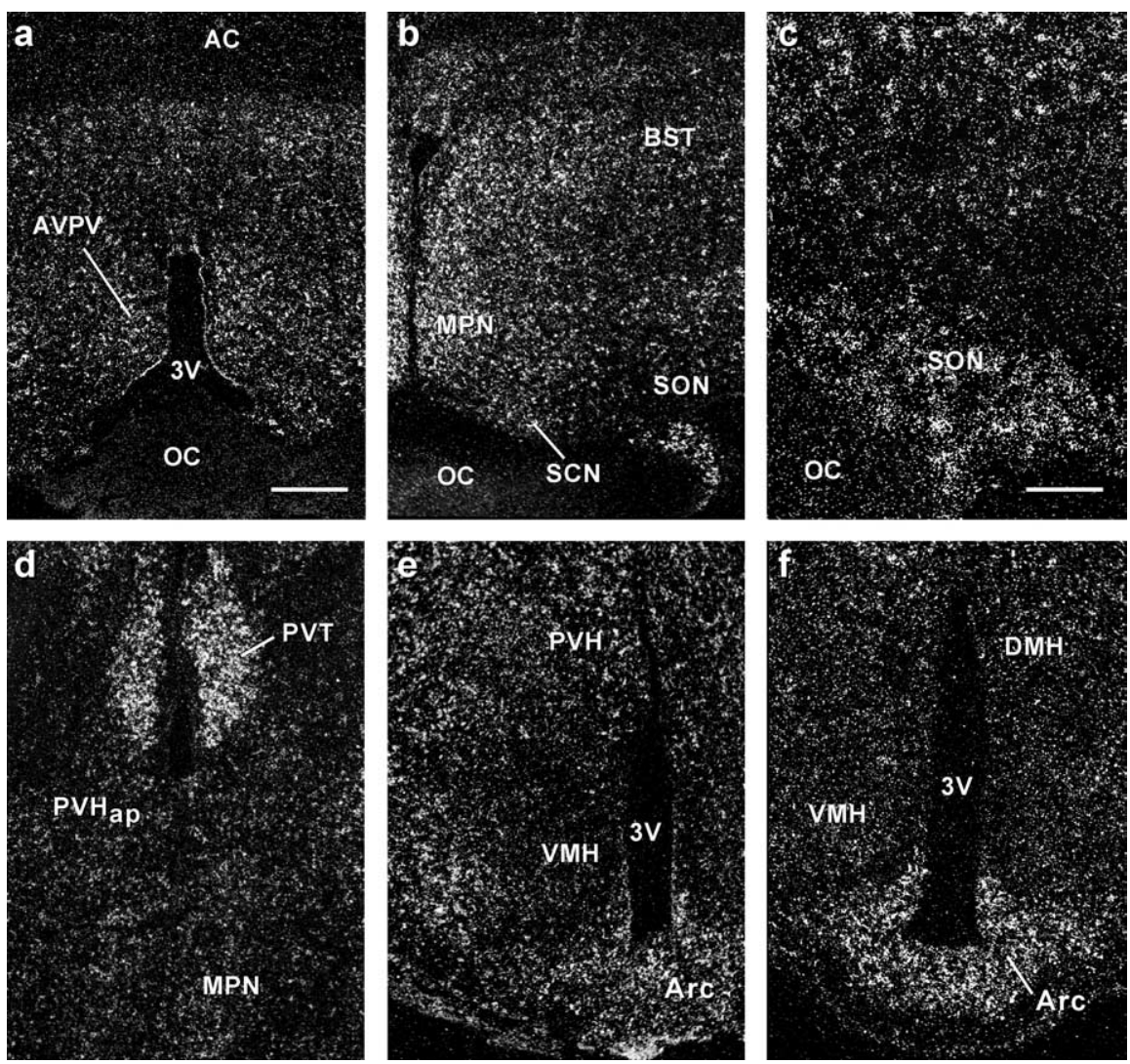

Figure 2. Distribution of Cav3.1 $\alpha 1$ subunit mRNA by in situ hybridization. Dark-field photomicrographs of coronal sections through the POA from rostral to caudal $(\boldsymbol{a}-\boldsymbol{d})$ and through the rostral and more caudal $\mathrm{MBH}(\boldsymbol{e}, \boldsymbol{f})$ that illustrate the distribution of autoradiographic grains indicative of Cav3.1 $\alpha 1$ mRNA in an E2-treated animal. AC, Anterior commissure; DMH, dorsomedial nucleus; $O C$, optic chiasm; PVHap, paraventricular nucleus of the hypothalamus anterior parvocellular part; PVT, paraventricular nucleus of the thalamus; $3 \mathrm{~V}$, third ventricle. Scale bars: (in $\boldsymbol{a}) \boldsymbol{a}, \boldsymbol{b}, \boldsymbol{d}-\boldsymbol{f}, 200 \mu \mathrm{m} ; \boldsymbol{c}, 100 \mu \mathrm{m}$. adding $50 \mathrm{U}$ of murine leukemia virus reverse Transcriptase (Applied Biosystems, Foster City, CA) as described previously (Qiu et al., 2003). PCR was performed using 2-3 $\mu \mathrm{l}$ of cDNA template from each RT reaction in a 30 $\mu \mathrm{l}$ of PCR volume containing the following: $3 \mu \mathrm{l}$ of $10 \times$ buffer (Promega, Madison, WI), $2.4 \mu \mathrm{l}$ of $\mathrm{MgCl}_{2}, 0.2 \mathrm{~mm}$ dNTPs, $0.2 \mu \mathrm{M}$ forward and reverse primers, $2 \mathrm{U}$ of TaqDNA polymerase and TaqStart antibody (Clontech, Palo Alto, CA). TaqDNA polymerase and TaqStart antibody were combined and incubated at room temperature for $5 \mathrm{~min}$, and the remainder of the reaction content was added to the tube and incubated at $94^{\circ} \mathrm{C}$ for $2 \mathrm{~min}$. Then, each reaction went through 50 cycles of amplification according to the following protocols: $94^{\circ} \mathrm{C}, 30 \mathrm{~s} ; 60-61^{\circ} \mathrm{C}, 1 \mathrm{~min} ; 72^{\circ} \mathrm{C}, 1 \mathrm{~min}$; with a final $72^{\circ} \mathrm{C}$ extension for $5 \mathrm{~min}$. Ten microliters of the PCR products were visualized with ethidium bromide on a $1.5 \%$ agarose gel.

All of the primers were synthesized by Invitrogen (Carlsbad, CA) and were as follows: guinea pig Cav $3.1 \alpha 1$ (GenBank accession number DQ 992353) 228 bp product, forward primer (bp 71-91) 5'-CGTGCTGGTCAACGTGGTGAT-3', reverse primer (bp 298-278) 5'-AGCGAGTGGGCTGCCTTGTAT-3'; guinea pig TH (GenBank accession number DQ 992354) $223 \mathrm{bp}$ product, forward primer (bp 64-83) 5'-TCCACGTTATACTGGTTCAC-3', reverse primer (bp 286-268) 5'-TTGCATCACTGAAGCTCTC-3'; guinea pig POMC (GenBank accession number S78260) 206 bp product, forward primer (bp 40-59) 5' -CTGGCCTTGCTGCTTCAGAT- $3^{\prime}$, reverse primer (bp 245-226) 5' -AAGTGGCCCGTGACGTACTT-3'.
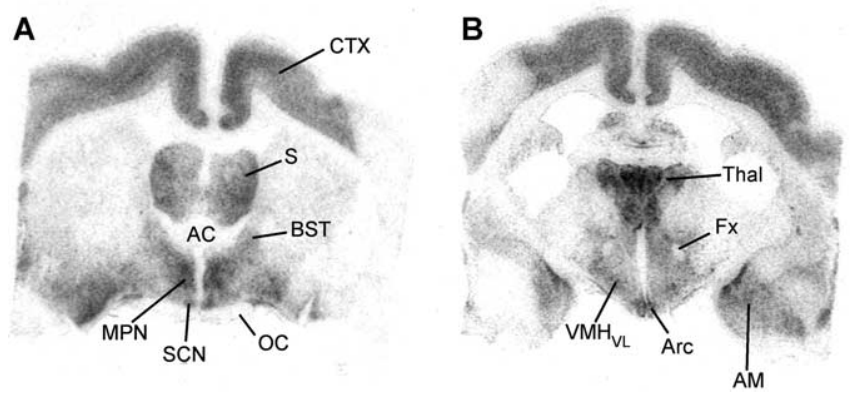

Figure 3. Film images Cav3.1 $\alpha 1$ mRNA distribution in rostral and more caudal brain regions. Bright-field view of film autoradiograms illustrating the distribution of Cav3.1 $\alpha 1$ mRNA in coronal sections from the $\mathrm{POA}(\boldsymbol{A})$ and the $\mathrm{MBH}(\boldsymbol{B})$ area in an E2-treated animal. The darker the images, the denser the mRNA expression. AM, Amygdala; CTX, cortex; Fx, fornix; $S$, septum; Thal, thalamus. See Figure 2 for additional abbreviations.

ing (Giloh and Sedat, 1982). Immunostained cells were analyzed and photographed using a Nikon (Tokyo, Japan) E800 microscope.

Dispersed single cell RT-PCR. Guinea pig $(350 \mu \mathrm{m})$ coronal hypothalamic slices from adult animals containing the arcuate nucleus were cut on a vibratome and prepared for cell dispersion as described previously (Qiu et al., 2003). The cells were isolated by trituration with flamepolished Pasteur pipettes, dispersed on a dish, and perfused continuously with aCSF at a rate of $1.5 \mathrm{ml} / \mathrm{min}$. Individual neurons were patched and harvested, and the pipette content was expelled into a siliconized microcentrifuge tube as described previously (Qiu et al., 2003). The harvested cell solution was denatured for $5 \mathrm{~min}$ at $65^{\circ} \mathrm{C}$ and cooled on ice for $5 \mathrm{~min}$, and then single-stranded cDNA was synthesized from cellular RNA by

\section{Results}

Guinea pig Cav3.1 $\alpha 1$ subunit PCR clone

To study the mRNA expression of the Cav3.1 $\alpha 1$ subunit in the guinea pig brain, we used PCR to clone a guinea pig-specific cDNA sequence that was $378 \mathrm{bp}$ in length. The guinea pig PCR product of the Cav3.1 $\alpha 1$ subunit was $87 \%$ homologous to the corresponding human sequence and $86 \%$ homologous to its mouse and rat counterparts. Our PCR clone consisted of sequences from the $3^{\prime}$-region (transmembrane segment 6 in repeat IV) of the Cav $3.1 \alpha 1$ subunit, an area that has relatively low homology with the $\alpha 1$ subunits of Cav3.2 and 3.3 channels (Lee et al., 1999).

Estrogen increases the mRNA expression of the $\alpha 1$ subunit of the Cav3.1 channel in the ventral basal hypothalamus and the pituitary by RPA measurements

We used a sensitive and quantitative RPA to quantify the mRNA levels of the Cav3.1 $\alpha 1$ subunit in the POA, MBH, and pituitary of the guinea pig. Linear regression analysis of the $\alpha 1 \mathrm{mRNA}$ sense standard curve revealed an $r$ value of 0.983 (Fig. 1A,B). The antisense $\left[{ }^{32} \mathrm{P}\right] \mathrm{rUTP}$-labeled riboprobe protected a single RNA band of $378 \mathrm{bp}$ in all tissues (Fig. 1C). To determine whether the mRNA expression of the Cav3.1 $\alpha 1$ subunit is modulated by E2, we measured its concentration in the POA, ventral mediobasal hypothalamus, and pituitary, all estrogen-sensitive structures, in ovariectomized animals that received oil $(n=3)$ or estrogen $(n=$ 3 ) injections 24 h earlier. Using radioimmunoassay for estrogen, 
OIL
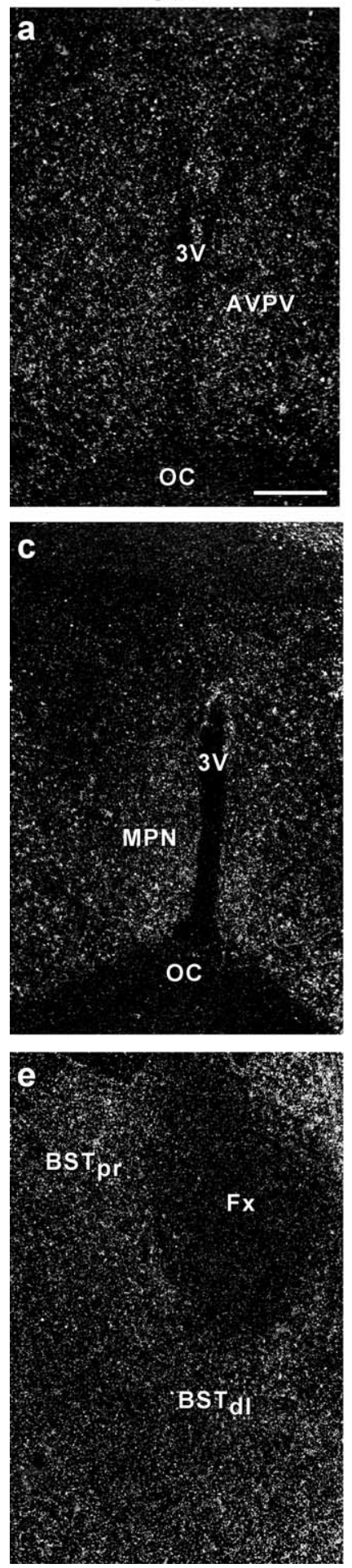

E2
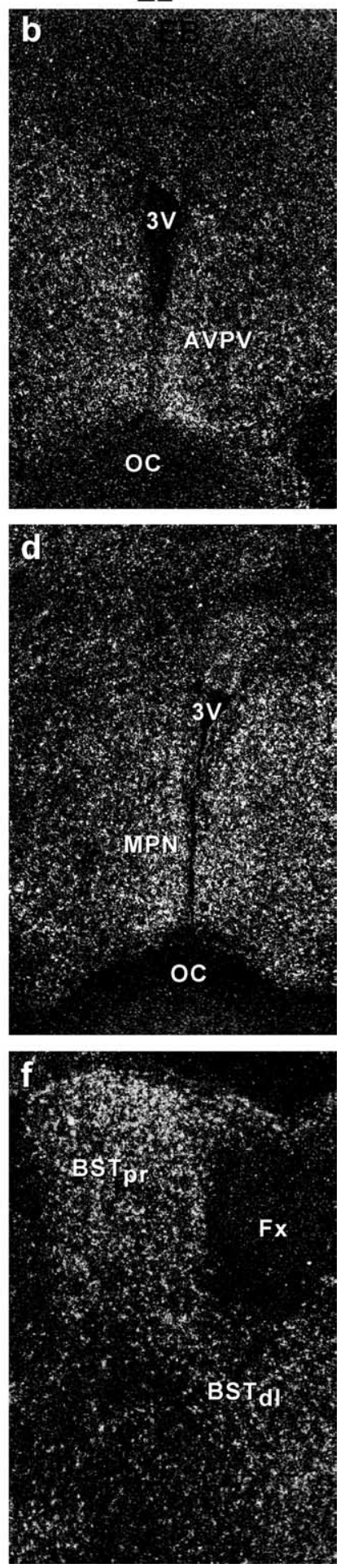

Figure 4. Emulsion autoradiograms of Cav3.1 $\alpha 1$ mRNA expression in the AVPV, MPN, and BST in ovariectomized oil- or E2-treated guinea pigs. Dark-field photomicrographs of matched sections from oil-treated $(\boldsymbol{a}, \boldsymbol{c}, \boldsymbol{e})$ and E2-treated $(\boldsymbol{b}, \boldsymbol{d}, \boldsymbol{f})$ guinea pigs illustrating autoradiographic grains indicative of Cav3.1 $\alpha 1$ mRNA expression in the AVPV, MPN, and BST. Scale bar, $200 \mu \mathrm{m}$ (for all photomicrographs). BSTpr, Principal nucleus of the BST; BSTdl, dorsolateral nucleus of the BST.

we confirmed that $24 \mathrm{~h}$ after a single injection of $17 \beta$-estradiol benzoate $(25 \mu \mathrm{g})$, the circulating levels of E2 were elevated $(202 \pm 20.6 \mathrm{pg} / \mathrm{ml} ; n=3)$ compared with the oil-injected group $(16.6 \pm 3.6 \mathrm{pg} / \mathrm{ml} ; n=3)$. These plasma levels of $\mathrm{E} 2$ are within the
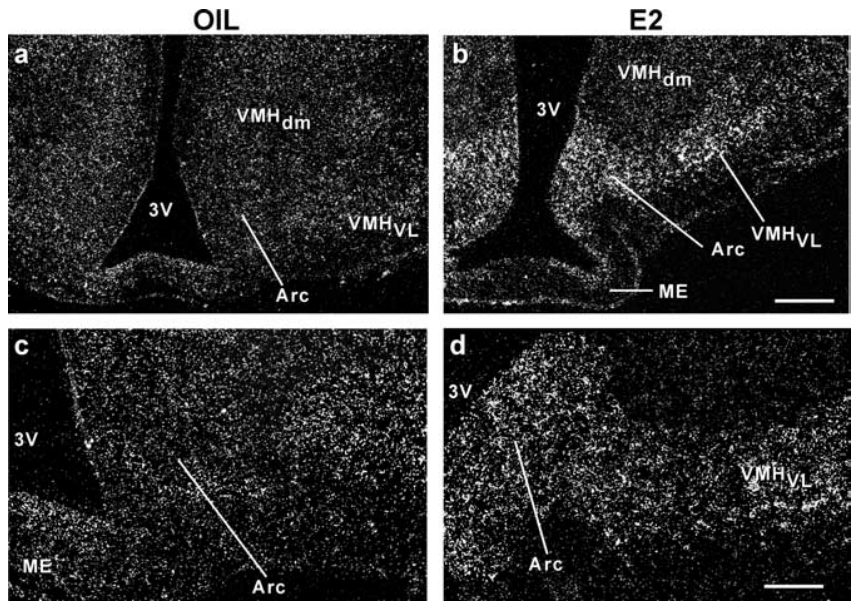

Figure 5. Emulsion autoradiograms of Cav3.1 $\alpha 1 \mathrm{mRNA}$ expression in the arcuate nucleus in E2-treated guinea pigs. Dark-field photomicrographs of matched sections from oil-treated ( $\boldsymbol{a}$, $\boldsymbol{c})$ and E2-treated $(\boldsymbol{b}, \boldsymbol{d})$ guinea pigs illustrating low-power $(\boldsymbol{a}, \boldsymbol{b})$ and high-power $(\boldsymbol{c}, \boldsymbol{d})$ views of Cav3.1 $\alpha 1$ mRNA expression in the arcuate region of the hypothalamus. Scale bars: $\boldsymbol{a}, \boldsymbol{b}, 200$ $\mu \mathrm{m} ; c, d, 100 \mu \mathrm{m}$.

physiological range in guinea pig and lead to inhibition of plasma $\mathrm{LH}$ that last for at least $36 \mathrm{~h}$ followed by a preovulatory surge of $\mathrm{LH}$ at $42 \mathrm{~h}$ (Wagner et al., 2001). The mRNA levels of the Cav3.1 $\alpha 1$ subunit were high in the POA and the $\mathrm{MBH}$, whereas the pituitary had much lower levels of $\alpha 1$ mRNA (Fig. $1 C, D$ ). When comparing the RNA from ovariectomized oil- and estrogentreated animals using RPA, we found that E2 treatment caused a significant increase in mRNA expression of the Cav3.1 $\alpha 1$ subunit in the $\mathrm{MBH}$ and the pituitary $(p<0.01)$ but not in the POA (Fig. 1C,D).

Distribution and estrogen regulation of the mRNA expression of the $\alpha 1$ subunit of Cav3.1 using in situ hybridization

To ascertain the distribution of the Cav3.1 $\alpha 1$ subunit in the guinea pig hypothalamus and to elucidate its regulation by E2 in specific nuclear groups, we performed in situ hybridization with radiolabeled riboprobes in ovariectomized oil- and E2-treated animals. Autoradiographic grains indicative of mRNA expression of the $\alpha 1$ subunit were found throughout the POA and $\mathrm{BH}$ region, including the anteroventral periventricular nucleus (AVPV), medial preoptic nucleus (MPN), bed nucleus stria terminalis (BST), suprachiasmatic nucleus (SCN), supraoptic nucleus (SON), paraventricular nucleus of the hypothalamus $(\mathrm{PVH})$, arcuate nucleus (Arc), ventromedial nucleus $(\mathrm{VMH})$, and dorsomedial nucleus of the hypothalamus (Figs. 2, 3). In these various brain regions, clusters of autoradiographic grains were found in cells with large pale nuclei identified with Nissl stain as neurons, suggesting that Cav3.1 $\alpha 1 \mathrm{mRNA}$ was expressed in neurons as described previously (Talley et al., 1999). The $\alpha 1$ subunit was also expressed in the cortex, septum, and thalamus of the female guinea pig (Figs. $2 d, 3$ ). There was no specific labeling with the sense probe (data not shown).

The distribution of the Cav3.1 $\alpha 1$ subunit was similar in oiland E2-treated females, with the exception that the mRNA expression was highly increased in a number of hypothalamic regions including the AVPV, MPN, BST, and the arcuate nucleus in E2-treated guinea pigs (Figs. 4, 5). Densitometry measurements of film images revealed that there were significantly higher mRNA levels of the Cav3.1 $\alpha 1$ subunit in medial preoptic nuclei, including the AVPV and MPN, the BST and the arcuate nucleus 

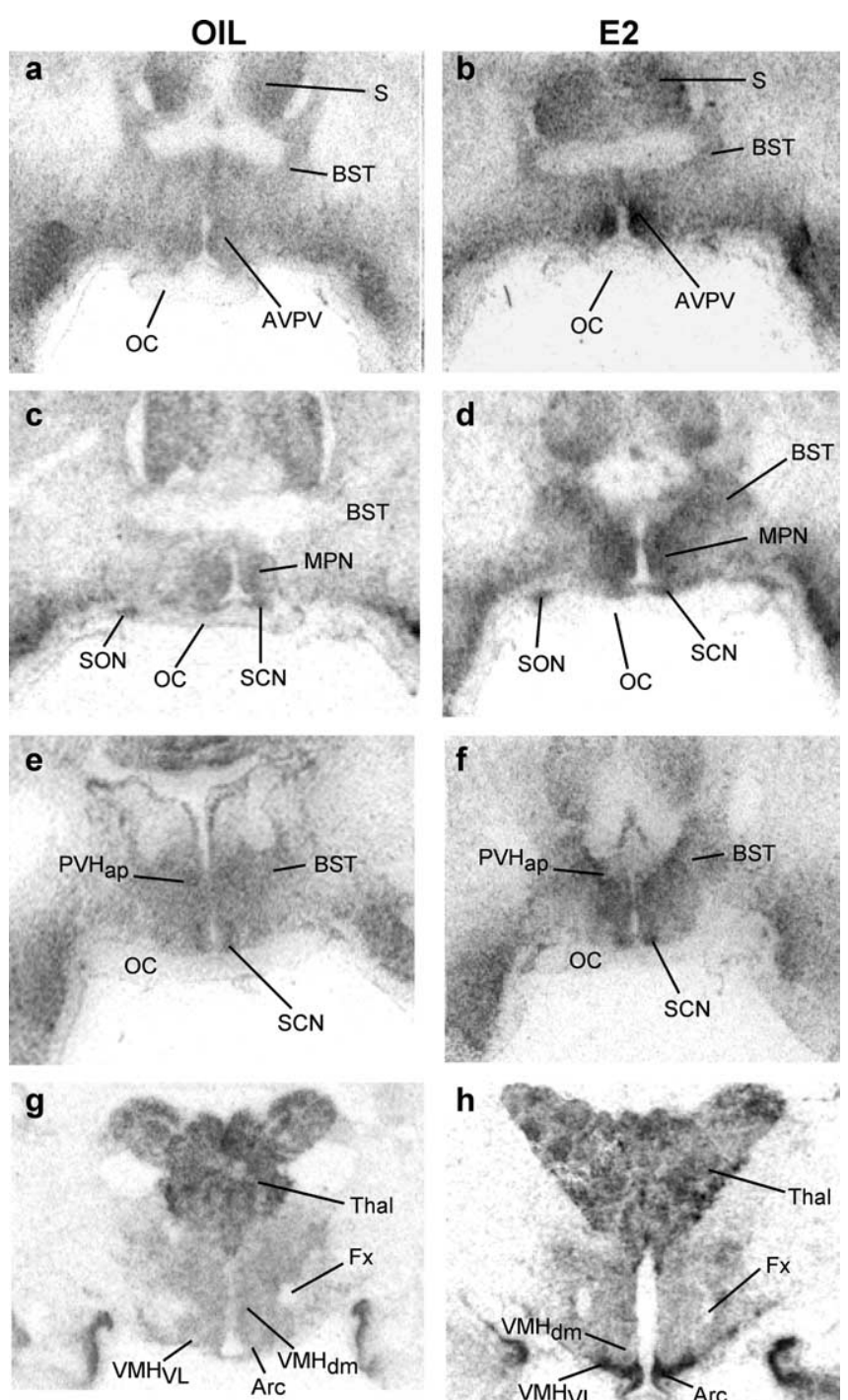
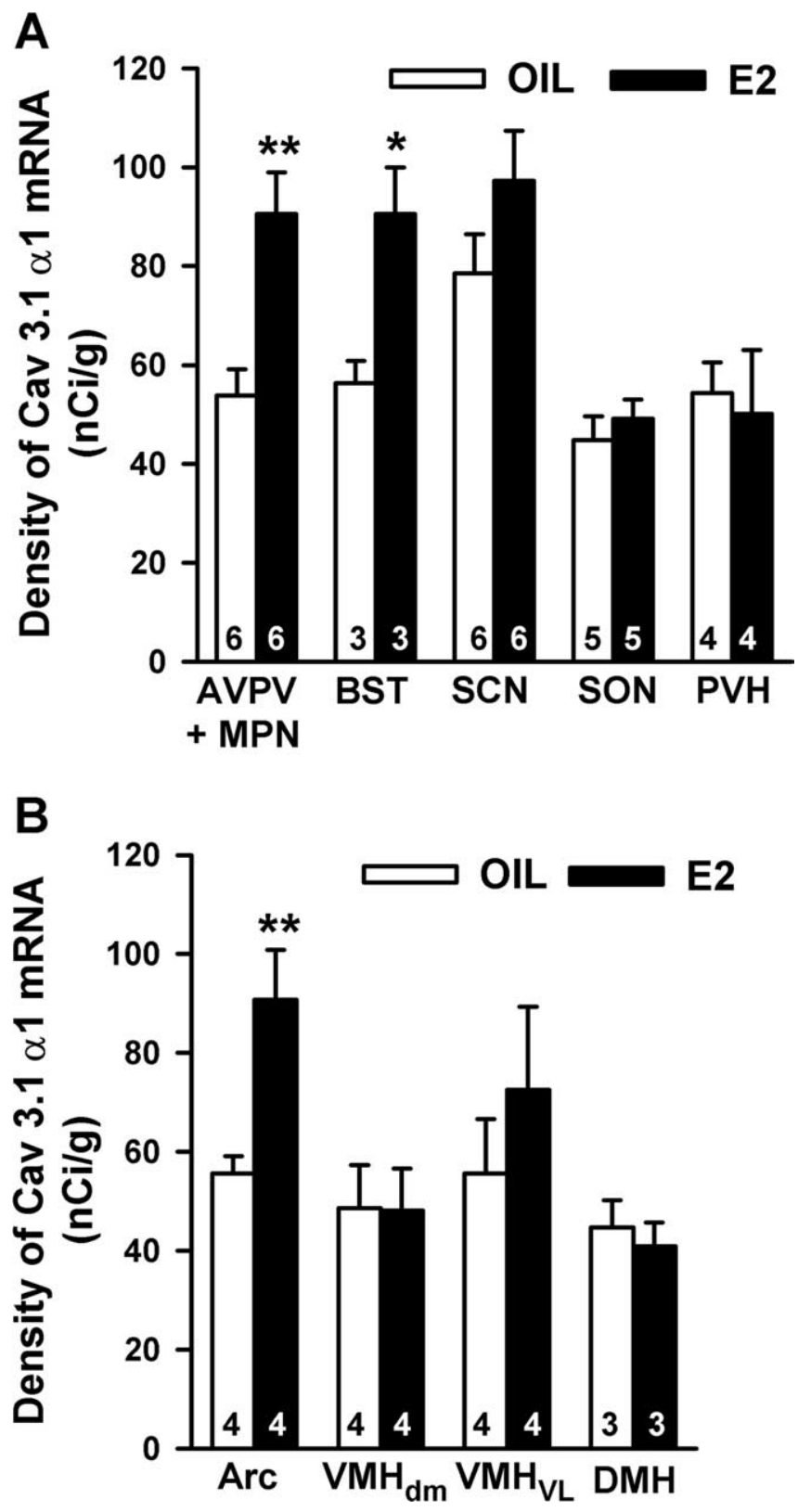

Figure 6. Film images of Cav3.1 $\alpha 1$ mRNA expression in ovariectomized oil- or E2-treated guinea pigs. Bright-field view of film autoradiograms illustrating the distribution of Cav3.1 $\alpha 1$ mRNA in coronal sections from rostral $(\boldsymbol{a}, \boldsymbol{b})$ to caudal $(\boldsymbol{g}, \boldsymbol{h})$ in oil-treated $(\boldsymbol{a}, \boldsymbol{c}, \boldsymbol{e}, \boldsymbol{g})$ and E2-treated $(\boldsymbol{b}, \boldsymbol{d}, \boldsymbol{f}, \boldsymbol{h})$ animals. The darker the images, the denser the mRNA expression. For abbreviations, see Figures 3 and 4.

in E2-treated compared with oil-treated females (Figs. 6, 7) $(p<$ $0.05-0.01 ; n=3-6)$. The $\alpha 1$ subunit was also increased in the SCN and the ventrolateral VMH in estrogen-treated females, although this did not reach statistical significance (Figs. 6, 7). Estrogen treatment did not alter Cav3.1 mRNA expression in the dorsal and central parts of the $\mathrm{VMH}$, as well as the SON and $\mathrm{PVH}$ (Figs. 5-7). In addition, the mRNA expression of the Cav3.1 $\alpha 1$ subunit was not different in the medial nuclei of the thalamus when the two groups of animals were compared (oil, $75.33 \pm 7.87$ $\mathrm{nCi} / \mathrm{g}$ vs $\mathrm{EB}, 63.70 \pm 17.11 \mathrm{nCi} / \mathrm{g} ; n=3-4)$.

\section{Estrogen increases the T-type calcium current in} arcuate neurons

To assess whether increased mRNA expression translated into increased cell function, we measured the whole-cell T-type calcium current, isolated by its kinetics and pharmacological blockade by nickel and mibefradil, in arcuate neurons from ovariectomized oil- and E2-treated guinea pigs. We found that $>60 \%$ ( $61 \%$ of the E2-treated, $n=44 ; 64 \%$ of the oil-treated, $n=31$ ) of

Figure 7. Group data of E2-induced increase in Cav3.1 $\alpha 1 \mathrm{mRNA}$ expression in the female guinea pig. Distribution and quantitative analysis of Cav3.1 $\alpha 1 \mathrm{mRNA}$ in tissue sections through the POA $(\boldsymbol{A})$ and BH $(\boldsymbol{B})$ regions obtained from oil- and E2-treated animals $(n=3-6)$. Values represent the mean density \pm SEM of Cav3.1 $\alpha 1 \mathrm{mRNA}$ levels (nanocuries per gram of tissue) in film images from the different brain regions. ${ }^{*} p<0.05,{ }^{* *} p<0.01$; two-tailed Student's $t$ test). For abbreviations, see Figures 3 and 4 . Error bars represent the mean \pm SEM.

the neurons exhibited T-type calcium currents (channels) (Fig. 8 ). First, we determined that there was no difference in the voltage dependence of activation in cells from control vehicle $\left(V_{1 / 2}=\right.$ $-59.6 \pm 1.0 \mathrm{mV}$; slope factor, $2.1 \pm 0.4 ; n=7)$ and cells from estrogen-treated animals $\left(V_{1 / 2}=-59.6 \pm 1.1 \mathrm{mV}\right.$; slope factor, $2.4 \pm 0.7 ; n=6)$, or voltage dependence of inactivation for control $\left(V_{1 / 2}=-85.8 \pm 0.8 \mathrm{mV}\right.$; slope factor, $\left.4.8 \pm 0.3 ; n=12\right)$ and estrogen-treated cells $\left(V_{1 / 2}=-87.5 \pm 0.9 \mathrm{mV}\right.$; slope factor, $5.1 \pm 0.5 ; n=6)$ (Fig. 8). Second, nickel $(100 \mu \mathrm{M})$ and mibefradil $(10 \mu \mathrm{M})$ were equally efficacious in antagonizing this lowthreshold current in both groups (for $\mathrm{Ni}^{+}, 58.4 \pm 8.3 \%$ inhibition, $n=10$; for mibefradil, $78.1 \pm 5.7 \%, n=7$ ). However, the whole-cell current (E2, $36.2 \pm 6.3 \mathrm{pA}, n=25$; oil, $18.3 \pm 3.8 \mathrm{pA}$, 
$n=23 ; p<0.05)$ and current density (E2, $0.97 \pm 0.17 \mathrm{pA} / \mathrm{pF}, n=25 ;$ oil, $0.48 \pm 0.10$ $\mathrm{pA} / \mathrm{pF}, n=23 ; p<0.05)$ were twofold greater in the arcuate neurons from E2treated compared with oil-treated females (Fig. 9b). In addition, under currentclamp conditions, E2 treatment increased the excitability of arcuate neurons as measured by the increased number of $\mathrm{Na}^{+}$ spikes during rebound burst firing (Fig. 10). Therefore, E2 not only increased Cav3.1 mRNA expression but also function in hypothalamic arcuate neurons. A subpopulation of the recorded neurons that expressed a T-type current was identified as dopaminergic (32\%), based on immunostaining for tyrosine hydroxylase (Fig. 9c). Approximately one-third of these were from the estrogen-treated and two-thirds were from the oil-treated group. Another subpopulation of recorded neurons, in which a T-type current was found, was identified as proopiomelanocortin (POMC) neurons (44\%) based on immunostaining for $\beta$-endorphin (Fig. $9 c)$. In support of these findings, we dispersed and harvested individual arcuate neurons and identified the expression of Cav3.1 $\alpha 1$ transcripts in $61 \%$ of these neurons $(n=51)$, including dopamine, POMC, and unidentified neurons, using single-cell RT-PCR (Fig. 9d).

\section{Discussion}

We found that the $\alpha 1$ subunit of the Cav3.1 gene is regulated by E2 in a number of hypothalamic regions and in the pituitary gland. In ovariectomized estrogen-treated animals, the mRNA expression is significantly increased in the MPOA, BST, and the arcuate nucleus as well as in the pituitary gland. In addition, we found that the whole-cell T-type calcium current is increased in arcuate neurons from E2-treated animals, which results in increased excitability (rebound burst firing). This is, to our knowledge, the first demonstration that estrogen can increase the mRNA expression and T-type calcium channel function in CNS neurons.

\section{Distribution and estrogen regulation of T-type channel subunits}

The $\alpha 1$ subunit of the Cav3.1 channel is distributed throughout the POA-BH region in the female guinea pig, as well as in the septum, thalamus, and cortex. These findings are in general agreement with previous observations that localized Cav3.1 $(\alpha 1 G)$ mRNA and protein in different brain regions including the hypothalamus of the male rat (Craig et al., 1999; Talley et al., 1999). In addition, using a sensitive and quantitative ribonuclease protection assay, we measured the Cav3.1 $\alpha 1$ subunit expression levels in the POA, mediobasal hypothalamus, and pituitary of the female guinea pig. We also determined that the mRNA expression of the Cav3.1 $\alpha 1$ subunit was significantly increased in the mediobasal hypothalamus and the pituitary in estrogentreated compared with oil-treated guinea pigs. The $\alpha 1$ subunit is expressed in the pituitary but at a much lower level compared with the brain as determined previously (Monteil et al., 2000). b

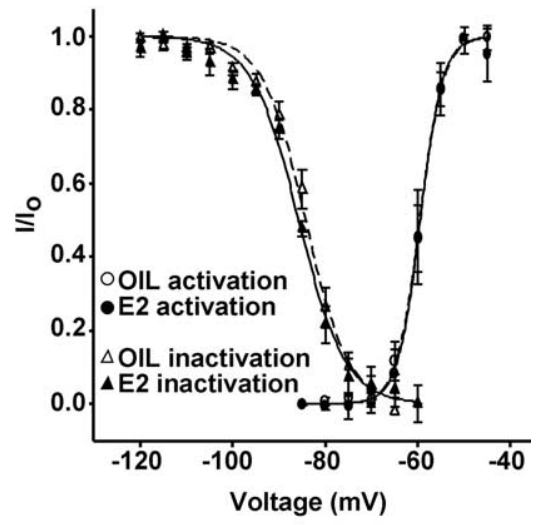

Figure 8. Lack of an effect of estrogen on voltage dependence of T-type channel activation and inactivation. $\boldsymbol{a}$, Procedures of mV in $5 \mathrm{mV}$ increments. On the right, traces obtained at the two different holding potentials were subtracted to isolate T-type 作 Materials and Methods. The mean $V_{1 / 2}$ values for T-type channel activation were not significantly different for control cells $\left(V_{1 / 2}=\right.$ 6). Similarly, $V_{1 / 2}$ values for channel steady-state inactivation were similar for both groups $\left(V_{1 / 2}=-85.8 \pm 0.8 \mathrm{mV}\right.$, slope 인닌

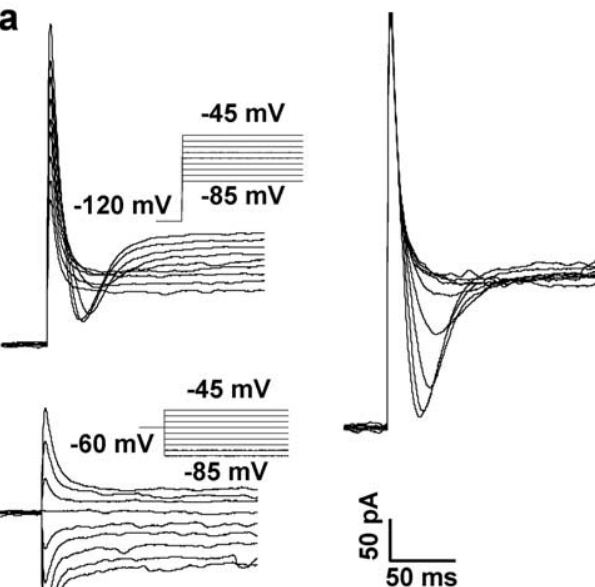


a

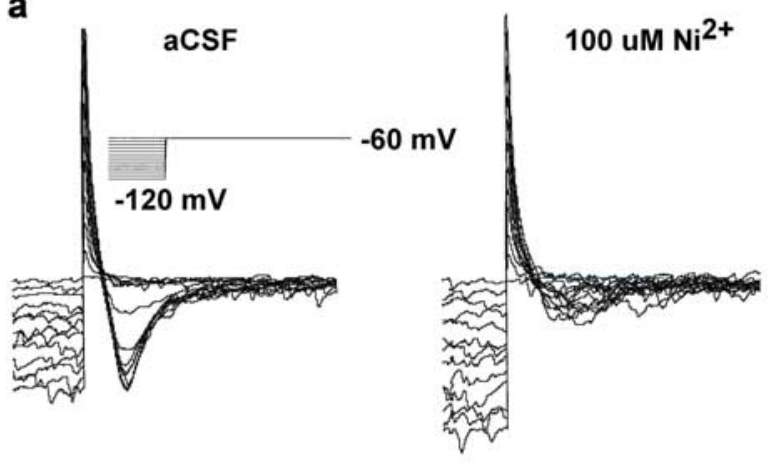

b

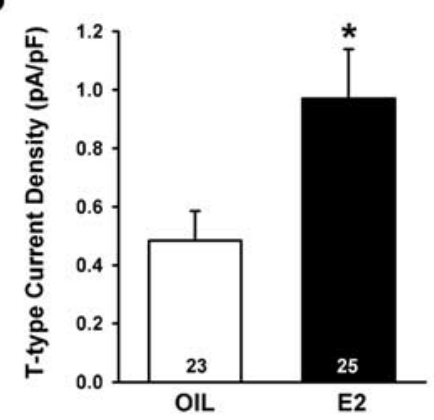

d

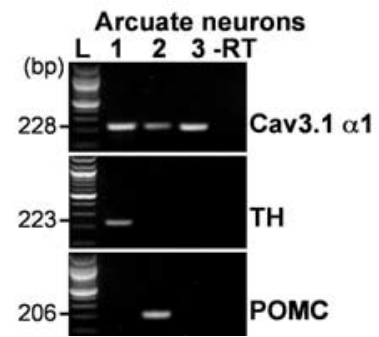

C
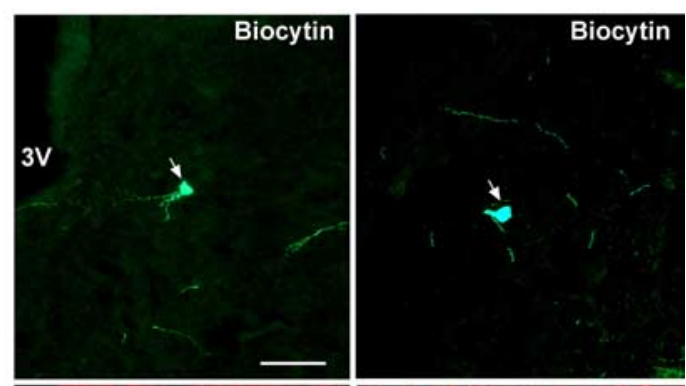

TH
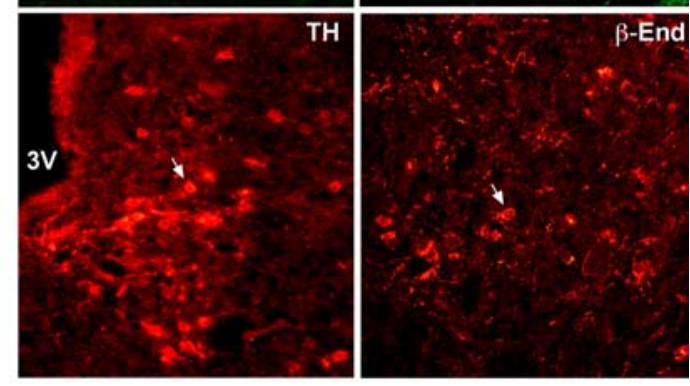

Figure 9. Estrogen increases the whole-cell T-type calcium current in arcuate neurons. $\boldsymbol{a}$, The peak current was obtained by applying conditioning pulses, $1 \mathrm{~s}$ in duration, ranging from -120 to $-65 \mathrm{mV}$ in $5 \mathrm{mV}$ increments and then a test pulse to -60 $\mathrm{mV}$ (inset), and the T-type calcium current in the arcuate neuron was completely blocked by $100 \mu \mathrm{m}$ nickel chloride. $\boldsymbol{b}$, The current amplitudes were normalized to the cell capacitance in all cases to calculate current density. Bar graphs summarize the density of T-type calcium current in arcuate neurons from oil-treated and E2-treated animals. The mean density was significantly greater in E2-treated $(0.97 \pm 0.17 \mathrm{pA} / \mathrm{pF} ; n=25)$ than in oil-treated $(0.48 \pm 0.10 \mathrm{pA} / \mathrm{pF} ; n=23)$ ovariectomized females. Error bars represent the mean \pm SEM tested per group. ${ }^{*} p<0.05$ versus vehicle. $c$, Double labeling of arcuate dopamine and POMC neuron that expressed a T-type current. Top, Biocytin-streptavidin-Cy2 labeling of arcuate neurons after whole-cell recording. Labeled fibers are extending toward medial (third ventricle, 3V), lateral, and ventral regions in both cells. Bottom, Immunocytochemical staining of TH and $\beta$-endorphin in the respective cells (arrows). Scale bar, $50 \mu \mathrm{m}$ (in all panels). $\boldsymbol{d}$, Expression of Cav3.1 $\alpha 1 \mathrm{mRNA}$ in arcuate neurons. Representative gel illustrating that single arcuate neurons expressed Cav3.1 $\alpha 1$ mRNA including TH, POMC, and unidentified neurons. One cell contained no RT as a negative control (-RT). In addition, the following controls were included: aCSF from the dispersed cellular milieu and a water blank, both of which were negative after RT-PCR (data not shown). The expected size of the PCR products is as follows (in bp): Cav3.1, 228; TH, 223; POMC, 206.

cedures (Niespodziany et al., 1999; van den Top et al., 2004; Molineux et al., 2006; Zhang et al., 2006). In accordance with the mRNA data, we found a significant increase in whole-cell T-type current in arcuate neurons from animals treated with estrogen for $24 \mathrm{~h}$, as well as an increase in rebound excitation and cell firing. These changes were not caused by alterations in channel activation/inactivation properties, because these remained the same in the two groups of animals. Therefore, the increased whole-cell current and excitability were most likely the result of increased expression of Cav3.1 channels. Rossier et al. (2003) reached similar conclusions after aldosterone treatment in human adrenocarcinoma H295R cells. In these cells, aldosterone treatment for $24 \mathrm{~h}$ selectively increased T-type calcium current amplitude without affecting L-type currents (Rossier et al., 2003). In addition, the mRNA expression of Cav3.2 $\alpha 1(\alpha 1 \mathrm{H})$, but not Cav3.1 $\alpha 1(\alpha 1 \mathrm{G})$, subunit was upregulated in these cells after aldosterone treatment via a mineralocorticoid receptor-mediated effect (Lesouhaitier et al., 2001; Rossier et al., 2003). Also, in cultured neonatal rat ventricular cardiomyocytes aldosterone and corticosterone increase T-type calcium channel (Cav3.2) mRNA expression, T-type current amplitude, and beating frequency, suggesting that the adrenal steroid-induced increase in mRNA expression and current amplitude have functional consequences (Lalevee et al., 2005). Therefore, it appears that aldosterone (corticosterone) has similar action on T-type calcium channels in the adrenocarcinoma cells and cardiomyocytes as E2 has on hypothalamic neurons with the exception that different subunits are involved. Studies are in progress to differentiate the effects of estrogen on Cav3.2 and $3.1 \alpha 1$ subunits in the brain and to elucidate which estrogen receptor is responsible for regulating their expression. Preliminary data suggest that the Cav3.1 $\alpha 1$ subunit is the most sensitive to estrogen in both the brain and pituitary (O.K.R., unpublished observations).

To our knowledge, increased neuronal T-type channel function in response to E2 treatment has not been reported previously. In fact, acute exposure to E2 in mouse sperm cells results in a reduction in T-type calcium-current amplitude (Espinosa et al., 2000). These actions in sperm, therefore, are opposite to those found in hypothalamic neurons and could represent the difference between acute and long-term (24 h) estrogen exposure. All (100\%) peripubertal rat gonadotropinreleasing hormone $(\mathrm{GnRH})$ neurons, prepared as a dispersed overnight culture, exhibit a T-type $\mathrm{Ca}^{2+}$ current, whereas only $50 \%$ of neonatal neurons exhibit the current (Kato et al., 2003). Therefore, it appears that the T-type current in GnRH neurons is developmentally regulated (i.e., becomes fully expressed in sexually mature animals) (but see Nunemaker et al., 2003), which supports the role of gonadal steroids in this process.

Dopamine-containing cells in the arcuate nucleus exhibit a low-threshold spike, an indication that these cells express T-type calcium channels (Loose et al., 1990). Indeed, we identified that arcuate dopamine neurons are among a group of arcuate neurons that exhibit T-type channels with Cav3.1/Cav3.2 characteristics, and the whole-cell current was augmented in estrogen-treated animals. Because arcuate dopamine neurons also express ER $\alpha$ (Lehman and Karsch, 1993; Skinner and Herbison, 1997; O.K.R., unpublished observations in the guinea pig), these neurons most 
a
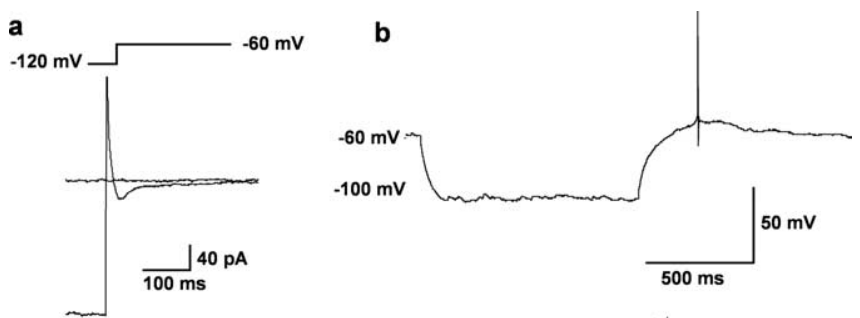

C
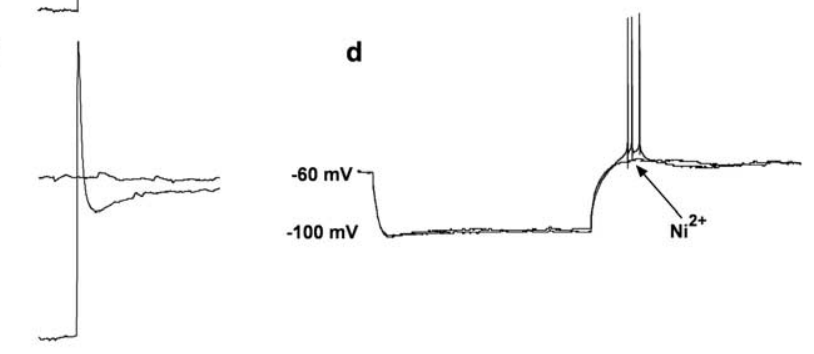
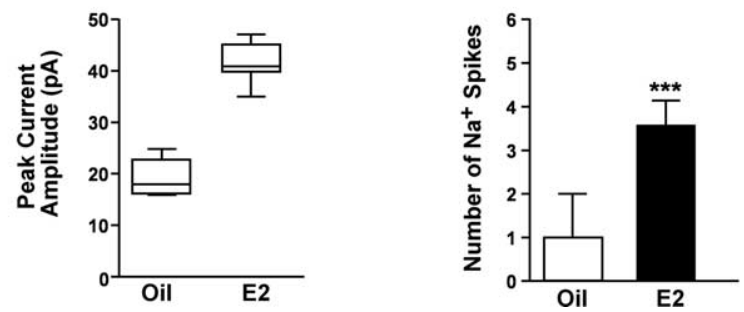

Figure 10. E2 increases rebound burst firing in arcuate neurons. Representative traces recorded in whole-cell voltage and current clamp from arcuate neurons in oil-treated $(\boldsymbol{a}, \boldsymbol{b})$ and E2-treated $(\boldsymbol{c}, \boldsymbol{d})$ animals. $\boldsymbol{a}$, In voltage-clamp mode in an arcuate neuron from oil-treated animal, depolarizing voltage commands stepped from $-120 \mathrm{mV}$ elicited a peak amplitude T-type current of $20 \mathrm{pA} \cdot \boldsymbol{b}$, In the current-clamp mode, the cell exhibited an LTS, which triggered a single $\mathrm{Na}^{+}$action potential after a hyperpolarizing current pulse to $-100 \mathrm{mV}$. c, Similar protocols in current-clamp and voltage-clamp modes were applied to another arcuate neuron from an E2-treated animal. In voltage-clamp mode, the voltage command evoked a peak amplitude T-type current of $44 \mathrm{pA}$. $\boldsymbol{d}$, The rebound from a hyperpolarization current pulse evoked a burst of $\mathrm{Na}^{+}$action potentials on the crest of a LTS in this arcuate neuron. $\mathrm{NiCl}_{2}(100 \mu \mathrm{m})$ abolished the LTS and accompanying $\mathrm{Na}^{+}$spikes (bottom trace). $\boldsymbol{e}$, Left, Box plot of the peak amplitudes of T-type current used for $\mathrm{Na}{ }^{+}$spike analysis in cells from oil-treated $(n=9)$ and E2-treated ( $n=7)$ groups. [The median is the center line in the box. The edges of the box represent the 75 th and the 25 th percentiles of the distribution. The vertical lines extending from the box represent the upper (90th percentile) and lower (10th percentile) limits of the distribution.] Right, Summary histograms of cells from oil-treated $(n=9)$ and E2-treated ( $n=$ 7) groups showing a significant increase in the number of rebound $\mathrm{Na}^{+}$spikes within the time course of the LTS $(500 \mathrm{~ms})$. Error bars represent the mean \pm SEM tested per group. ${ }^{* * *} p<0.005$ versus vehicle.

likely exhibit increased activity and increased dopamine release in estrogen-treated animals. Physiologically this is important because estrogen stimulates prolactin synthesis and secretion from pituitary lactotropes, but arcuate dopamine neurons directly inhibit lactotropes via the $\mathrm{D}_{2}$ receptor (Neill and Frawley, 1983; Schaufele, 1999). Thus, estrogen acts at the pituitary as well as the brain to maintain proper prolactin synthesis and secretion. We also identified T-type currents in POMC neurons, and subpopulation of POMC neurons also express ER $\alpha$ (Skinner and Herbison, 1997; O.K.R., unpublished observations in the guinea pig). Therefore, effects of estrogen on T-type channels may be one mechanism by which estrogen increases the activity of these neurons, which are critical neurons in the hypothalamic circuits controlling energy homeostasis (Cone, 2005).

Cav3.1 mRNA is also localized to other hypothalamic neurosecretory neurons and plays a critical role in sculpturing burst firing activity. For example, supraoptic and paraventricular nu-

cleus neurons express Cav3.1 mRNA. We have shown that the T-type current in supraoptic vasopressin neurons is associated with a phasic burst firing (Erickson et al., 1993a,b). In addition, the SCN exhibits a relatively dense expression of Cav3.1 $\alpha 1$ mRNA. Interestingly, the whole-cell T-type calcium current amplitude in the ventrolateral SCN exhibits diurnal variation and T-type channels are mediators of glutamate-induced phase delays (Kim et al., 2005). Therefore, these channels may be important for diurnal and other biological rhythms regulated by the SCN (Kalra, 1986; Herbison, 1998). The T-type current is known for its ability to trigger burst firing in many other neurons, including DRG and thalamic neurons (White et al., 1989; Huguenard, 1996). In this respect, the thalamocortical neurons in Cav3.1 $(\alpha 1 \mathrm{G})$ knock-out (KO) animals loose their ability for burst firing, and these animals exhibit resistance to absence seizures, further substantiating a role of T-type channels (Cav3.1) in these events (Kim et al., 2001).

\section{Estrogen regulation of T-type channel expression in the pituitary}

In this study, we measured mRNA expression of T-type Cav3.1 $\alpha 1$ subunit of calcium channels in the guinea pig pituitary gland and found that this expression was increased in estrogen-treated animals. This is also a novel finding, because T-type channel regulation by estrogen in the pituitary has not been reported. It is well documented that low-voltage activated (T-type) channels are involved in triggering exocytosis in pituitary cells (Keja and Kits, 1994; Tomic et al., 1999; Mansvelder and Kits, 2000; Stojikovic et al., 2005). The T-type calcium channels are expressed in melanotropes, gonadotropes, lactotropes, and somatotropes, and most of these pituitary cells also express ER $\alpha$ (Mitchner et al., 1998; Van Goor et al., 2001). Therefore, estrogen may regulate Cav3.1 expression in most, if not all, of these different pituitary cells, and this may in part mediate its role in regulating hormone release. It could be that $\mathrm{T}$-type $\mathrm{Ca}^{2+}$ channels are expressed in all secretory (pituitary) and neurosecretory (hypothalamic) cells and play a critical role in generating rhythmic activity linked to hormone release. Cav3 KO mice may help elucidate the role of these low-threshold $\mathrm{Ca}^{2+}$ channels in hormone release.

In summary, our findings indicate that T-type calcium channels are widely distributed in the hypothalamus and also expressed in the pituitary. Moreover, the mRNA expression and function of these channels are regulated by estrogen, which highlights their critical role in neuroendocrine regulation.

\section{References}

Bajic VB, Tan SL, Chong A, Tang S, Ström A, Gustafsson JA, Lin C-Y, Liu E (2003) Dragon ERE finder ver. 2: a tool for accurate detection and analysis of estrogen response elements in vertebrate genomes. Nucleic Acids Res 31:3605-3607.

Catterall WA, Striessnig J, Snutch TP, Perez-Reyes E (2003) International union of pharmacology. XXXIX. Compendium of voltage-gated ion channels: calcium channels. Pharmacol Rev 55:575-578.

Catterall WA, Perez-Reyes E, Snutch TP, Striessnig J (2005) International union of pharmacology. XLVIII. Nomenclature and structure-function relationship of voltage-gated calcium channels. Pharmacol Rev 57: 411-425.

Chemin J, Monteil A, Perez-Reyes E, Bourinet E, Nargeot J, Lory P (2002) Specific contribution of human T-type calcium channel isotypes (alpha(1G), alpha(1H) and alpha(1I)) to neuronal excitability. J Physiol (Lond) 540:3-14.

Cone RD (2005) Anatomy and regulation of the central melanocortin system. Nat Neurosci 8:571-578.

Craig PJ, Beattie RE, Folly EA, Banerjee MD, Reeves MB, Priestley JV, Carney 
SL, Sher E, Perez-Reyes E, Volsen SG (1999) Distribution of the voltagedependent calcium channel $\mathrm{a}_{1 \mathrm{G}}$ subunit mRNA and protein throughout the mature rat brain. Eur J Neurosci 11:2949-2964.

Dave JR, Rubinstein N, Eskay RL (1985) Evidence that $\beta$-endorphin binds to specific receptors in rat peripheral tissues and stimulates the adenylate cyclase-adenosine $3^{\prime}, 5^{\prime}$-monophosphat system. Endocrinology 117:1389-1396.

DonCarlos LL, Monroy E, Morrell JI (1991) Distribution of estrogen receptor-immunoreactive cells in the forebrain of the female guinea pig. J Comp Neurol 305:591-612.

Erickson KR, Rønnekleiv OK, Kelly MJ (1993a) Electrophysiology of guinea-pig supraoptic neurones: role of a hyperpolarization-activated cation current in phasic firing. J Physiol (Lond) 460:407-425.

Erickson KR, Rønnekleiv OK, Kelly MJ (1993b) Role of a T-type calcium current in supporting a depolarizing potential, damped oscillations, and phasic firing in vasopressinergic guinea pig supraoptic neurons. Neuroendocrinology 57:789-800.

Espinosa F, Lopez G, Munoz-Garay C, Felix R, De l V, Kopf GS, Visconti PE, Darszon A (2000) Dual regulation of the T-type $\mathrm{Ca}(2+)$ current by serum albumin and beta-estradiol in mammalian spermatogenic cells. FEBS Lett 475:251-256.

Fisher TE, Bourque CW (1995) Voltage-gated calcium currents in the magnocellular neurosecretory cells of the rat supraoptic nucleus. J Physiol (Lond) 486:571-580.

Giloh H, Sedat JW (1982) Fluorescence microscopy: reduced photobleaching of rhodamine and fluorescein protein conjugates by $\mathrm{n}$-propyl gallate. Science 217:1252-1255.

Herbison AE (1998) Multimodal influence of estrogen upon gonadotropinreleasing hormone neurons. Endocr Rev 19:302-330.

Hoffman NW, Kim YI, Gorski RA, Dudek FE (1994) Homogeneity of intracellular electrophysiological properties in different neuronal subtypes in medial preoptic slices containing the sexually dimorphic nucleus of the rat. J Comp Neurol 345:396-408.

Huguenard JR (1996) Low-threshold calcium currents in central nervous system neurons. Annu Rev Physiol 58:328-348.

Jamali KA, Naylor BR, Kelly MJ, Rønnekleiv OK (2003) Effect of $17 \beta$ Estradiol on mRNA expression of large-conductance, voltage dependent, and calcium-sensitive potassium channel $\alpha$ and $\beta$ subunits in the guinea pig. Endocrine 20:227-237.

Kalra SP (1986) Neural circuitry involved in the control of LHRH secretion: a model for preovulatory LH release. In: Frontiers in Neuroendocrinology (Ganong WF, Martini L, eds), pp 31-75. New York: Raven.

Kato M, Ui-Tei K, Watanabe M, Sakuma Y (2003) Characterization of voltage-gated calcium currents in gonadotropin-releasing hormone neurons tagged with green fluorescent protein in rats. Endocrinology 144: $5118-5125$.

Keja JA, Kits KS (1994) Single-channel properties of high-and low-voltageactivated calcium channels in rat pituitary melanotropic cells. J Neurophysiol 71:840-855.

Kelly MJ, Rønnekleiv OK (1994) Electrophysiological analysis of neuroendocrine neuronal activity in hypothalamic slices. In: Methods in neurosciences: pulsatility in neuroendocrine systems (Levine JE, ed), pp 47-67. San Diego: Academic.

Kim D, Song I, Keum S, Lee T, Jeong MJ, Kim SS, McEnery MW, Shin HS (2001) Lack of the burst firing of thalamocortical relay neurons and resistance to absence seizures in mice lacking alpha(1G) T-type $\mathrm{Ca}(2+)$ channels. Neuron 31:35-45.

Kim DY, Choi HJ, Kin JS, Kim YS, Jeong DU, Shin HC, Kim MJ, Han H-C, Hong SK, Kim YI (2005) Voltage-gated calcium channels play crucial roles in the glutamate-induced phase shifts of the rat suprachiasmatic circadian clock. Eur J Neurosci 21:1215-1222.

Lalevee N, Rebsamen MC, Barrere-Lemaire S, Perrier E, Nargeot J, Benitah J-P, Rossier MF (2005) Aldosterone increases T-type calcium channel expression and in vitro beating frequency in neonatal rat cardiomyocytes. Cardiovasc Res 67:216-224.

Lee J-H, Daud AN, Cribbs LL, Lacerda AE, Pereverzev A, Klockner U, Schneider T, Perez-Reyes E (1999) Cloning and expression of a novel member of the low voltage-activated T-type calcium channel family. J Neurosci 19:1912-1921.

Lehman MN, Karsch FJ (1993) Do gonadotropin-releasing hormone, tyrosine hydroxylase, and $\beta$-endorphin-immunoreactive neurons contain estrogen receptors? A double-label immunocytochemical study in the Suffolk ewe. Endocrinology 133:887-895.

Lesouhaitier O, Chiappe A, Rossier MF (2001) Aldosterone increases t-type calcium currents in human adrenocarcinoma (H295R) cells by inducing channel expression. Endocrinology 142:4320-4330.

Loose MD, Rønnekleiv OK, Kelly MJ (1990) Membrane properties and response to opioids of identified dopamine neurons in the guinea pig hypothalamus. J Neurosci 10:3627-3634.

Ma YJ, Dissen GA, Rage F, Ojeda SR (1996) RNase protection assay. Methods 10:273-278.

Mansvelder HD, Kits KS (2000) All classes of calcium channel couple with equal efficiency to exocytosis in rat melanotropes, inducing linear stimulus-secretion coupling. J Physiol (Lond) 526:327-339.

McCormick DA, Huguenard JR (1992) A model of the electrophysiological properties of thalamocortical relay neurons. J Neurophysiol 68:1384-1400.

McRory JE, Santi CM, Hamming KS, Mezeyova J, Sutton KG, Baillie DL, Stea A, Snutch TP (2001) Molecular and functional characterization of a family of rat brain T-type calcium channels. J Biol Chem 276:3999-4011.

Merchenthaler A, Lane MV, Numan S, Dellovade TL (2004) Distribution of estrogen receptor $\alpha$ and $\beta$ in the mouse central nervous system in vivo autoradiographic and immunocytochemical analyses. J Comp Neurol 473:270-291

Mitchner NA, Garlick C, Ben-Jonathan N (1998) Cellular distribution and gene regulation of estrogen receptors $\alpha$ and $\beta$ in the rat pituitary gland. Endocrinology 139:3976-3983.

Mitra SW, Hoskin E, Yudkovitz J, Pear L, Wilkinson HA, Hayashi S, Pfaff DW, Ogawa S, Rohrer SP, Schaeffer JM, McEwen BS, Alves SE (2003) Immunolocalization of estrogen receptor beta in the mouse brain: Comparison with estrogen receptor alpha. Endocrinology 144:2055-2067.

Molineux ML, McRory JE, McKay BE, Hamid J, Mehaffey WH, Rehak R, Snutch TP, Zamponi GW, Turner RW (2006) Specific T-type calcium channel isoforms are associated with distinct burst phenotypes in deep cerebellar nuclear neurons. Proc Natl Acad Sci USA 103:5555-5560.

Monteil A, Chemin J, Bourinet E, Mennessier G, Lory P, Nargeot J (2000) Molecular and functional properties of the human $\mathrm{a}_{1 \mathrm{G}}$ subunit that forms T-type calcium channels. J Biol Chem 275:6090-6100.

Neill JD, Frawley LS (1983) Neuroendocrine regulation of prolactin secretion in primates. In: The anterior pituitary gland (Bhatnager AS, ed), pp 253-267. New York: Raven.

Niespodziany I, Derambure P, Poulain P (1999) Properties of T-type calcium current in enkephalinergic neurones in guinea-pig hypothalamic slices. Pflügers Arch Eur J Physiol 437:871-880.

Nunemaker CS, DeFazio RA, Moenter SM (2003) Calcium current subtypes in GnRH neurons. Biol Reprod 69:1914-1922.

Olster DH (1994) Hypothalamic estrogen receptor-immunoreactivity in prepubertal vs adult female guinea pigs. J Neuroendocrinology 6:617-625.

Perez-Reyes E (1999) Three for T: molecular analysis of the low voltageactivated calcium channel family. Cell Mol Life Sci 56:660-669.

Perez-Reyes E (2003) Molecular physiology of low-voltage-activated T-type calcium channels. Physiol Rev 83:117-161.

Perez-Reyes E, Cribbs LL, Daud A, Lacerda AE, Barclay J, Williamson MP, Margaret F, Rees M, Lee J-H (1998) Molecular characterization of a neuronal low-voltage-activated T-type calcium channel. Nature 391:896-900.

Qiu J, Bosch MA, Tobias SC, Grandy DK, Scanlan TS, Rønnekleiv OK, Kelly MJ (2003) Rapid signaling of estrogen in hypothalamic neurons involves a novel $\mathrm{G}$ protein-coupled estrogen receptor that activates protein kinase C. J Neurosci 23:9529-9540.

Rønnekleiv OK, Loose MD, Erickson KR, Kelly MJ (1990) A method for immunocytochemical identification of biocytin-labeled neurons following intracellular recording. BioTechniques 9:432-438.

Rossier MF, Lesouhaitier O, Perrier E, Bockhorn L, Chiappe A, Lalevee N (2003) Aldosterone regulation of T-type calcium channels. J Steroid Biochem Mol Biol 85:383-388.

Schaufele F (1999) Regulation of estrogen receptor activation of the prolactin enhancer/promoter by antagonistic activation function-2-interacting proteins. Mol Endocrinol 13:935-945.

Skinner DC, Herbison A (1997) Effects of photoperiod on estrogen receptor, tyrosine hydroxylase, neuropeptide $\mathrm{Y}$ and $\beta$-endorphin immunoreactivity in the ewe hypothalamus. Endocrinology 138:2585-2595. 
Stojikovic SS, Zemková H, Van Goor F (2005) Biophysical basis of pituitary cell type-specific $\mathrm{Ca}^{2+}$ signaling-secretion coupling. Trends Endocrinol Metab 16:152-159.

Sundgren-Andersson AK, Johansson S (1998) Calcium spikes and calcium currents in neurons from the medial preoptic nucleus of rat. Brain Res 783:194-209.

Talley EM, Cribbs LL, Lee JH, Daud A, Perez-Reyes E, Bayliss DA (1999) Differential distribution of three members of a gene family encoding low voltage-activated (T-type) calcium channels. J Neurosci 19:1895-1911.

Tomic M, Koshimizu T-A, Yuan D, Andric S, Zivadinovic D, Tojilkovic SS (1999) Characterization of a plasma membrane calcium oscillator in rat pituitary somatotrophs. J Biol Chem 274:693-702.

van den Top M, Lee K, Whyment AD, Blanks AM, Spanswick D (2004) Orexigen-sensitive NPY/AgRP pacemaker neurons in the hypothalamic arcuate nucleus. Nat Neurosci 7:493-494.

Van Goor F, Zivadinovic D, Stojikovic SS (2001) Differential expression of ionic channels in rat anterior pituitary cells. Mol Endocrinology 15:1222-1236.

Wagner EJ, Reyes-Vazquez C, Rønnekleiv OK, Kelly MJ (2000) The role of intrinsic and agonist-activated conductances in determining the firing patterns of preoptic area neurons in the guinea pig. Brain Res 879:29-41.

Wagner EJ, Rønnekleiv OK, Bosch MA, Kelly MJ (2001) Estrogen biphasically modifies hypothalamic GABAergic function concomitantly with negative and positive control of luteinizing hormone release. J Neurosci 21:2085-2093.

Warembourg M, Leroy D (2004) Comparative distribution of estrogen receptor alpha and beta immunoreactivities in the forebrain and the midbrain of the female guinea pig. Brain Res 1002:55-66.

White G, Lovinger DM, Weight FF (1989) Transient low-threshold $\mathrm{Ca}^{2+}$ current triggers burst firing through an afterdepolarizing potential in an adult mammalian neuron. Proc Natl Acad Sci USA 86:6802-6806.

Williams SR, Toth TI, Turner JP, Hughes SW, Crunelli V (1997) The 'window' component of the low threshold $\mathrm{Ca}^{2+}$ current produces input signal amplification and bistability in cat and rat thalamocortical neurones. J Physiol (Lond) 505:689-705.

Zhang L, Doroshenko P, Cao XY, Irfan N, Coderre E, Kolaj M, Renaud LP (2006) Vasopressin induces depolarization and state-dependent firing patterns in rat thalamic paraventricular nucleus neurons in vitro. Am J Physiol Regul Integr Comp Physiol 290:R1226-R1232. 